\title{
SUMUT TUAN RUMAH MTQN 27
}

Oleh Shohibul Anshor Siregar

Ada beberapa rujukan untuk lebih meyakini bahwa Medan dan sekitarnya sebagai tuan rumah penyelenggaraan MTQN 27 bulan Oktober mendatang di Medan dan sekitarnya, yakni sejumlah perhelatan berskala nasional yang pernah diselenggarakan di sini. Pertama, MTQN 2 tahun 1971. Dengan begitu Sumatera Utara sebagai tuan rumah MTQN 27 tahun 2018 adalah menjadi tuan rumah untuk kedua kalinya.

Kedua, Legacy Pon III dari Gubernur Abdul Hakim Harahap. Pada tahun 1953 Sumut menjadi tuan rumah PON III. Khabarnya nanti pada tahun 2024 Sumut akan menjadi tuan rumah perhelatan yang sama, namun bersama dengan Aceh. Gubernur Abdul Hakim Harahap membangun Stadion Teladan untuk kepentingan PON III. Legacy itu juga ditambah dengan pemberian nama-nama jalan cabang olahraga di sekitar Teladan. Sayang sekali Jalan Keliling Stadion Teladan beberapa tahun lalu sudah diganti nama dengan nama lain yang mengasosiasikan patung kuda Sisingamangaraja dekat lokasi itu. Masalah paling serius justru nama itu terkait dengan kerusuhan saat demonstrasi menuntut provinsi Tapanuli awal Februari 2009 yang mengakibatkan meninggalnya Ketua DPRDSU Abdul Azis Angkat yang justru namanya tak dianggap penting untuk diabadikan di kota Medan.

Ketiga, Legacy Marah Halim Cup. Tak ada event sepakbola sehebat Mahal Cup yang diselenggarakan oleh Gubernur Marah Halim Harahap. Kehebatannya terletak pada keberhasilan mengundang kesebelasan berbagai negara dan keteraturan even yang menjadi agenda FIFA itu. Sebagai ksatria sebetulnya orang Sumut wajib menyuarakan agar event dan nama di balik even dimasukkan ke dalam tinta emas sejarah persepakbolaan Indonesia. Bayangkan, sejak tahun 1972 Mahal Cup diselenggarakan. Sebanyak 3 kali South Korea menjadi juara (1981, 1983 dan 1985). Burma, Jepang dan PSMS Medan masing-masing pernah menjadi juara sebanyak 2 kali (Burma: 1978 dan 1979; Jepang 1974 dan 1988; PSMS Medan 1972 dan 1973). Masing-masing pernah sekali menjadi juara tercatat Australia (1976), China (1991), Al-Jaish (1984), Medan Jaya (1995), Netherland Amateur (1980), Persija Jakarta (1977), FC Wageningen (1989), Western Australi (1975), West Germany (1982), dan Yugoslavia (1986).

Keempat, Kongres Himpunan Indonesia untuk Pengembangan Ilmu-Ilmu Sosial (HIPIIS) Akhir Kejayaan Orde Baru. Kongres HIPIIS ke-VII pada 18-22 Maret 1997 di Medan, yang mengambil tema "Mempersiapkan Masyarakat Profesional Indonesia 2003". Dibanding dengan Kongresnya di Malang pada tanggal 13-17 Nopember 1979 yang melahirkan wacana besar 'Kemiskinan Struktural' Kongres ke-VII di Medan tak memberi catatan penting kecuali perkuatan dukungan ilmuan sosial kepada rezim yang berkuasa sambil membayangkan Indonesia tinggal landas setelah menyelenggarakan pembangunan selama 3 dasawarsa di bawah kepemimpinan Soeharto.

Secara formal rujukan-rujukan itu sangat bermanfaat dan memiliki kredit point tersendiri untuk meyakini bahwa Medan (Sumut) tak perlu diragukan sebagai tuan rumah untuk MTQN 27 bulan Oktober mendatang.

\section{Hospitality}

Bolehlah dipetik sejumlah rujukan yang patut dijadikan benchmarking. Atas dasar penelitiannya, Muzna Noohu (2017) memberi daftar 13 kota dan atau negara di dunia yang 
paling ramah terhadap kenyamanan kebutuhan muslim (halal). Sesuai urutannya ialah Penang (Malaysia), Bodrum (Turki), Osaka (Jepang), Kolkata (India), Fez (Maroko), St Julians (Malta), Abu Dhabi (Uni Emirat Arab), Lombok (tentu sebelum belakangan ini ditimpa musibah gempa berkepanjangan), Hamburg (Jerman), Sri Lanka (tak diberi rincian nama kota tertentu), Aqaba (Jordania), Jeju (Korea Selatan) dan Negara kota Singapura. Sebagai negara dengan mayoritas penduduk muslim di dunia, Indonesia perlu membenahi diri untuk mengejar standar universal sesuai ketentuan shariah.

Bagaimana pun juga MTQN 27 sangat memerlukan diterapkannya konsep halal tourism, sesuatu yang sesuai dengan tingkat ketidak-nyamanan berislam di Indonesia masih dianggap menjadi hal aneh kalau bukan menakutkan. Menurut Muslim Friendly Tourism (MFT) dalam Understanding the Demand and Supply Sides in the OIC Member Countries (2015) pertumbuhan turis dari dunia Islam untuk tahun 2000, 2010, dan 2014 masing-masing adalah 25 juta, 98 juta, dan 116 juta. Untuk tahun 2020 diperkirakan menjadi 180 juta. Indonesia sebagai negara berpenduduk mayoritas muslim entah mengapa memang belum menganggap dirinya seperlu dan sepenting negara-negara lain untuk berbenah, padahal secara ekonomi transaksi dalam mekanisme halal tourism begitu membantu signifikan pada negara yang harus berhutang kemana-mana karena ingin dipandang gagah membangun infrastruktur.

Sebatas tekad memang disebut bahwa indonesia sedang berbenah. Berdasarkan data Kementerian Pariwisata, pihaknya kini sudah menyusun strategi mengembangkan lebih lanjut tempat wisata halal di Indonesia. Ada ambisi untuk menarik 3,8 juta pengunjung Muslim untuk 2018, dan 5 juta pada 2019, yang akan berkontribusi terhadap target 20 juta pengunjung internasional di tahun yang sama. Kota-kota yang paling direkomendasikan untuk investasi dalam program ini ada di Aceh, Sumatera Barat, Jakarta, Jawa Barat, dan tentu Lombok.

Bagaimana dengan Sumut? Terutama dengan Danau Tobanya, Sumut masih sedang belum akan memulai serius menyusun strategi halal tourism. Jika tahun ini Sumut akan menjadi tuan rumah MTQ Nasional ke XXVII, maka tak salah agenda nasional itu diintegrasikan dengan konsep pengembangan halal tourism yang tentu tak cuma berurusan soal infrastruktur yang akan dibenahi, tetapi juga aspek hospitality. Hospitality itu lebih mengacu nilai dan budaya.

Konsep hospitality atau keramahtamahan (hasanatun lidhiyafah) mengacu pada hubungan antara tamu dan tuan rumah, sebuah ekspresi kebajikan dari jiwa agung yang peduli terhadap seluruh alam semesta melalui ikatan kemanusiaan bersifat theocentric. Umumnya orang akan berbicara hospitality sebatas jaminan kenyamanan hunian dan lingkungan dari aspek kebersihan, check in dan check out, komunikasi dan informasi, nilai dan keakuratan dalam layanan dan lain-lain yang untuk itu misalnya Andrey Fradkin, Riley Newman \& Rebecca Rosenfelt (2018) memberi kota dan hunian turis di Amerika indeks dengan urutan Tampa, Mendocino, Eugene, Bend, Raleigh, Memphis, Madison, Nashville, Tucson, dan Danau Tahoe.

Konsep hospitality untuk kebutuhan halal tourism tak berhenti sebatas itu, karena asumsi utamanya merujuk pada maqasid al-shari'ah, yakni bahwa hukum Islam memiliki tujuan mewujudkan kemakmuran bagi manusia di dunia dan akhirat. Dilihat dari skala prioritasnya, Maqasid al-shari'ah memiliki 3 tingkatan terdiri dari manfaat penting (al-Dharuriyyat), manfaat utama (al-Hajiyyat) dan manfaat pelengkap (al-Tahsiniyyat), yang ketika dibreakdown akan menyangkut 5 dimensi penting yakni al-din (agama), nafs (jiwa), nasl 
(garis keturunan), mal (harta), dan 'aql (kecerdasan). Secara kultural, historis, sosiologis, demografis dan geopolitik, kota Medan dengan motto "Medan Rumah Kita" rasanya memiliki potensi besar untuk adaptasi konsep hospitality di atas.

\title{
Partisipasi Masyarakat
}

Perhelatan kegamaan seperti MTQ akan dipersepsi berbeda-beda antara satu dan lain kelompok dan kedudukan masyarakat (agama dan afiliasinya, kelas sosial, pekerjaan dan jabatan). Persepsi orang muslim pasti berbeda dengan non-muslim. Interest politisi juga akan berbeda dengan pemimpin ormas, pelaku ekonomi dan tingkatannya juga akan berpersepsi beragam, apalagi pejabat pemerintahan. Pejabat pemerintaan pusat dan daerah juga memiliki interesting point yang berbeda (lihat model berikut).

Tindakan terencana dan terukur sangat diperlukan. Prasyarat untuk memicu partisipasi terluas itu tentu saja memerlukan tindakan-tindakan tererncana dan terukur. Partisipasi substansial selalu memerlukan kecukupan informasi, konsultasi, mekanisme pengambilan keputusan kolektif yang dengan sendirinya membuat semua stakeholder merasa beftanggungjawab untuk melahirkan tindakan bersama serta dorongan untuk membantu orang lain yang bersifat independen untuk melakukan apa yang mereka bisa dan inginkan dalam kerangka partisipasi mensukseskan kerja bersama itu.

\begin{abstract}
Alaram Politik
Adalah hal yang sangat masuk akal untuk menduga bahwa event apa pun, apalagi yang bersifat nasional, terlebih yang bersifat keagamaan, teristimewa menyangkut umat berpopulasi terbesar di negeri ini (Islam), akan dianggap penting untuk dikapitalisasi bagi keperluan popularitas dan elektabilitas politik menuju perhelatan bulan April 2019 yang akan datang. Agenda suksesi 2019 sudah cukup lama diawali dengan fenomena polarisasi, bahkan dikhotomi sosial terlebih hingga hari ini kita hanya beroleh dua pasangan bakal capres/cawapres (Joko Widodo-KH Ma'ruf Amin dan Prabowo Subianto-Sandiaga Salahuddin Uno). Tentu saja kekuatan-kekuatan politik lain (partai) tidak mungkin akan melewatkan perhitungan untuk mengkapitalisasi event ini bagi political benefitnya masingmasing.
\end{abstract}

Belum lama ini di Medan sebuah perhelatan ganda di lokasi berdekatan berlangsung. Pertama, deklarasi \#2019GantiPresiden. Kedua, Deklarasi \#Jokowi2Periode. Dari pendekatan keamanan dan hukum mestinya kedua kegiatan itu tak diperkenankan terselenggara pada hari yang sama apalagi di lokasi yang sangat berdekatan.

Rentetan Deklarasi \#2019GantiPresiden di berbagai kota khususnya Pekanbaru dan Surabaya telah mengundang eskalasi pro dan kontra. Sebagian mengatakan ini berpotensi makar, sebagian meyakininya sebagai ruang partisipasi politik publik yang wajib dijamin sesuai konstitusi untuk membangun demokrasi dan kehidupan negara yang sehat.

Jika tema MTQN XXVII ini saja sudah berbunyi "MTQ Mewujudkan Revolusi Mental Menuju Insan Yang Qur'ani” maka tafsir politik terhadapnya pun tak mungkin dihindari. Karena itu secara politik tema itu tidak menjadi suatu keheranan dalam masyarakat yang sudah dikhotomik ini diasosiasikan untuk kapitalisasi dukungan Jokowi 2 Periode. 
Tahun 2015 Tilawah Al-qur'an Langgam Jawa yang diklaim Langgam Nusantara diperkenalkan melalui istana. Bagi sebagian umat muslim yang memahami MTQ tak berhenti sebatas festival seni dan kemerduan bacaan (di Indonesia) ini juga menjadi salah satu alaram politik. "Insan Yang Qur'ani" yang disebut dalam tema MTQN XXVII tidak tercapai dengan sendirinya. Ini memerlukan usaha mendekatkan hingga tak ada jarak antara substansi (nilai Islam) dengan rutinisme atau seremoni negara.

Penulis adalah dosen FISIP UMSU. Koordinator Umum Pengembangan Basis Sosial Inisiatif \& Swadaya ('nBASIS). 